\title{
Weakly Polar Aprotic Ionic Liquids Acting as Strong Dissociating Solvent: A Typical "Ionic Liquid Effect" Revealed by Accurate Measurement of Absolute $\mathrm{p} K_{\mathrm{a}}$ of Ylide Precursor Salts
}

\author{
Chong Mao, ${ }^{\dagger,+}$ Zedong Wang, ${ }^{\ddagger,+}$ Zhen Wang, ${ }^{\dagger}$ Pengju Ji*,† and Jin-Pei Cheng, ${ }^{*,+,}$ \\ ${ }^{\dagger}$ Center of Basic Molecular Science (CBMS), Department of Chemistry, Tsinghua University, Beijing, \\ 100084, China. \\ ${ }^{\ddagger}$ State Key Laboratory of Elemento-organic Chemistry, Collaborative Innovation Centre of Chemical \\ Science and Engineering, Nankai University, Tianjin, 300071, China. \\ E-mails: jipengju@mail.tsinghua.edu.cn; jinpei_cheng@mail.tsinghua.edu.cn \\ ${ }^{+}$These authors contributed equally to this work
}

\section{Table of Contents}

1. Experimental..........................................................................S2

2. The base and standard $\mathrm{p} K_{\mathrm{a}}$ values of indicators used in this work.......................S2

3. UV-vis spectra of the representative titration with base and acid in four RTILs..........S3

4. Synthesis and characterization amine triflates.......................................S8

5. Reference............................................................................S11 


\section{Experimental}

Materials. ILs, indicators and the base used in this work were synthesized and purified based on previous work. ${ }^{1}$ P-substituted triphenylphosphonium and the N-substituted pyridinium salts (1-8); 2,4,6-collidine hydrochloride, triethylammonium hydrochloride and piperidine hydrochloride were commercially available and were carefully recrystallized and dried before used as substrates. The synthesis and spectra of amine triflimide salts (9-11) used in this work were introduced previously. ${ }^{2}$ The phenol salts (12) were synthesized according to the reference. ${ }^{3}$ The water content of ILs was less than $10 \mathrm{ppm}$, which was determined by Karl-Fischer method.

$\mathbf{p} \boldsymbol{K}_{\mathbf{a}}$ Measurement. The principle and measurement procedures were similar to these previously reported. ${ }^{1}$ In brief, taking a typical run as an example, the $\mathrm{p} K_{\mathrm{a}}$ measurement was started by degassing and weighing the UV cell, followed by adding $1.5 \mathrm{ml} \mathrm{IL}$ and $40 \mathrm{mg}$ base into the cell. An indicator with known $\mathrm{p} K_{\mathrm{a}}$ was added dropwisely after the cell was weighted again and a baseline was recorded on the UV instrument. Monitored by the UV instrument, after the base was fully consumed by normally 6-8 drops of the indicator, an excess amount of indicator solution was added. During the titration, the spectrum and weight for each addition was recorded. Next the target acid of interest was added in several portions. The weight of the UV cell and the corresponding spectrum were also recorded upon each addition. The corresponding $\mathrm{p} K_{\mathrm{a}}$ was obtained with the data derived from the change of absorbance and the amount of acid added.

\section{The base and Standard $\mathrm{p} K_{\mathrm{a}}$ values of indicators used in this work}

The indicators used in this work were fluorene or phenol based compounds (A-E), of which the $\mathrm{p} K_{\mathrm{a}}$ scales were accurately established previously. ${ }^{1}$

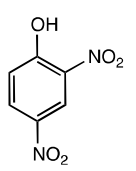

A

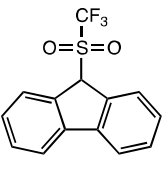

B

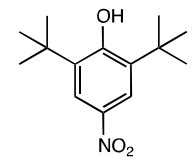

C

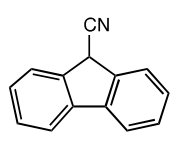

D

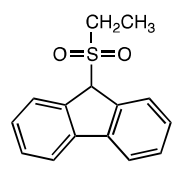

E

Tabel S1 The indicators used in this work and their $\mathrm{p} K_{\mathrm{a}}$ values in four RTILs (SD $\leq \pm 0.05 \mathrm{p} K$ units)

\begin{tabular}{|c|c|c|c|c|}
\hline entry & $\begin{array}{c}\mathrm{p} K_{\mathrm{a}} \\
{[\mathrm{BMIM}]\left[\mathrm{NTf}_{2}\right]}\end{array}$ & $\begin{array}{c}\mathrm{p} K_{\mathrm{a}} \\
{[\mathrm{BMPY}]\left[\mathrm{NTf}_{2}\right]}\end{array}$ & $\begin{array}{c}\mathrm{p} K_{\mathrm{a}} \\
{[\mathrm{BMIM}][\mathrm{OTf}]}\end{array}$ & $\begin{array}{c}\mathrm{p} K_{\mathrm{a}} \\
{\left[\mathrm{BM}_{2} \mathrm{IM}\right]\left[\mathrm{NTf}_{2}\right]}\end{array}$ \\
\hline A & $12.1_{5}$ & 12.8 & 9.5 & $12.9_{5}$ \\
\hline B & $12.6_{5}$ & 12.6 & 10.0 & 13.2 \\
\hline C & 15.1 & 15.4 & 12.3 & 15.9 \\
\hline D & 16.7 & $16.5_{5}$ & 13.8 & 17.4 \\
\hline $\mathbf{E}$ & $20.2_{5}$ & 20.2 & 17.4 & 21.1 \\
\hline
\end{tabular}
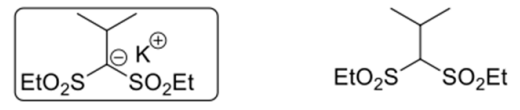

$\mathrm{p} K_{\mathrm{a}}=15.3(\mathrm{DMSO})$

The base (a carbanion) used in this work and its conjugated acid. 


\section{UV-vis spectra of the representative titration with base and acid in four RTILs}

The UV-vis spectra of titration processes for the measurement of acidity for these compounds are similar, the following are several representative spectra.
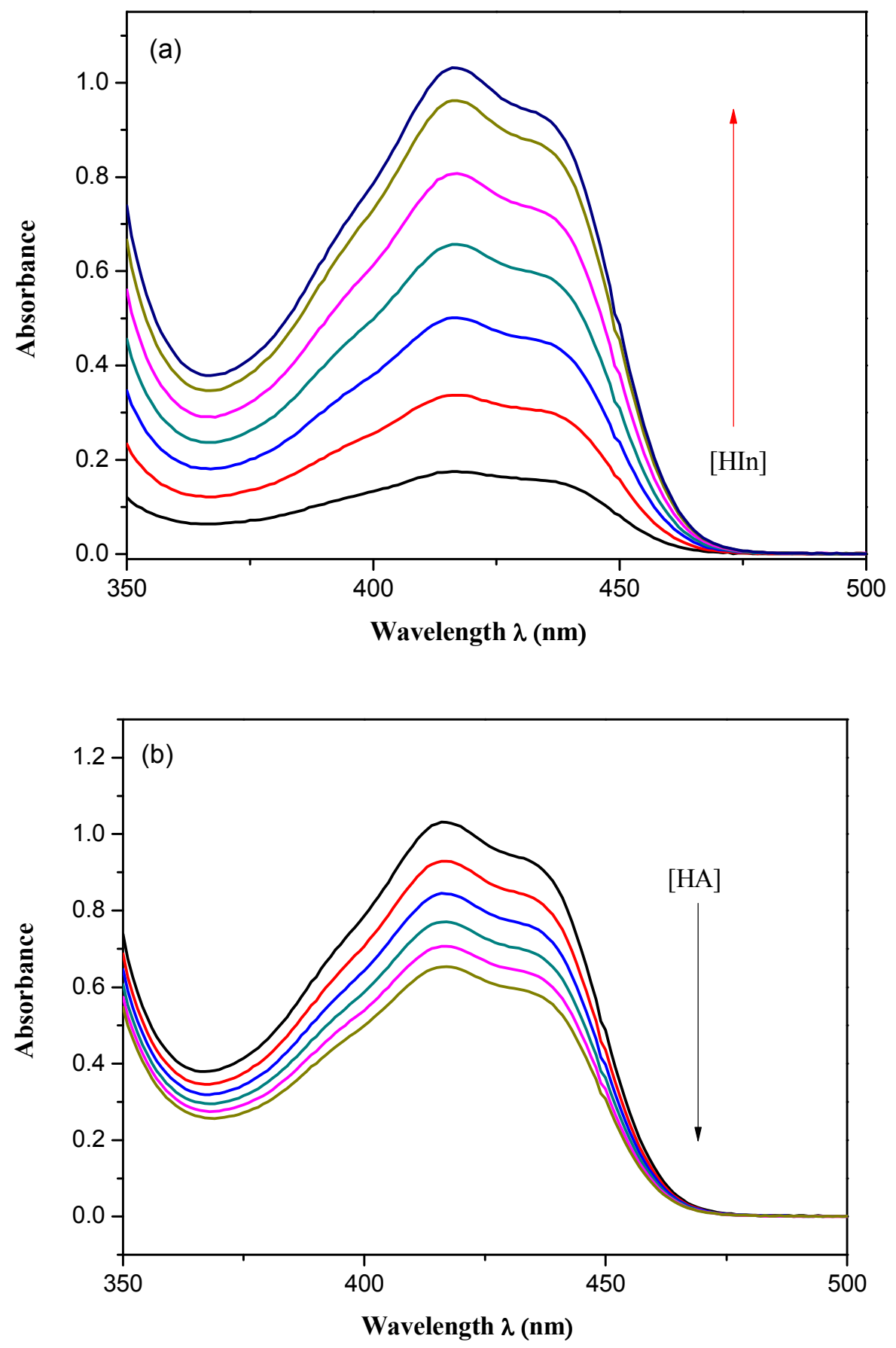

Figure S1 (a) The increasing absorbance during the deprotonation of the indicator $\mathbf{D}$ by the base. (b) The decreasing absorbance during the titration of the indicator anion by $4 \mathbf{a}$ in [BMIM] $\left[\mathrm{NTf}_{2}\right]$. 

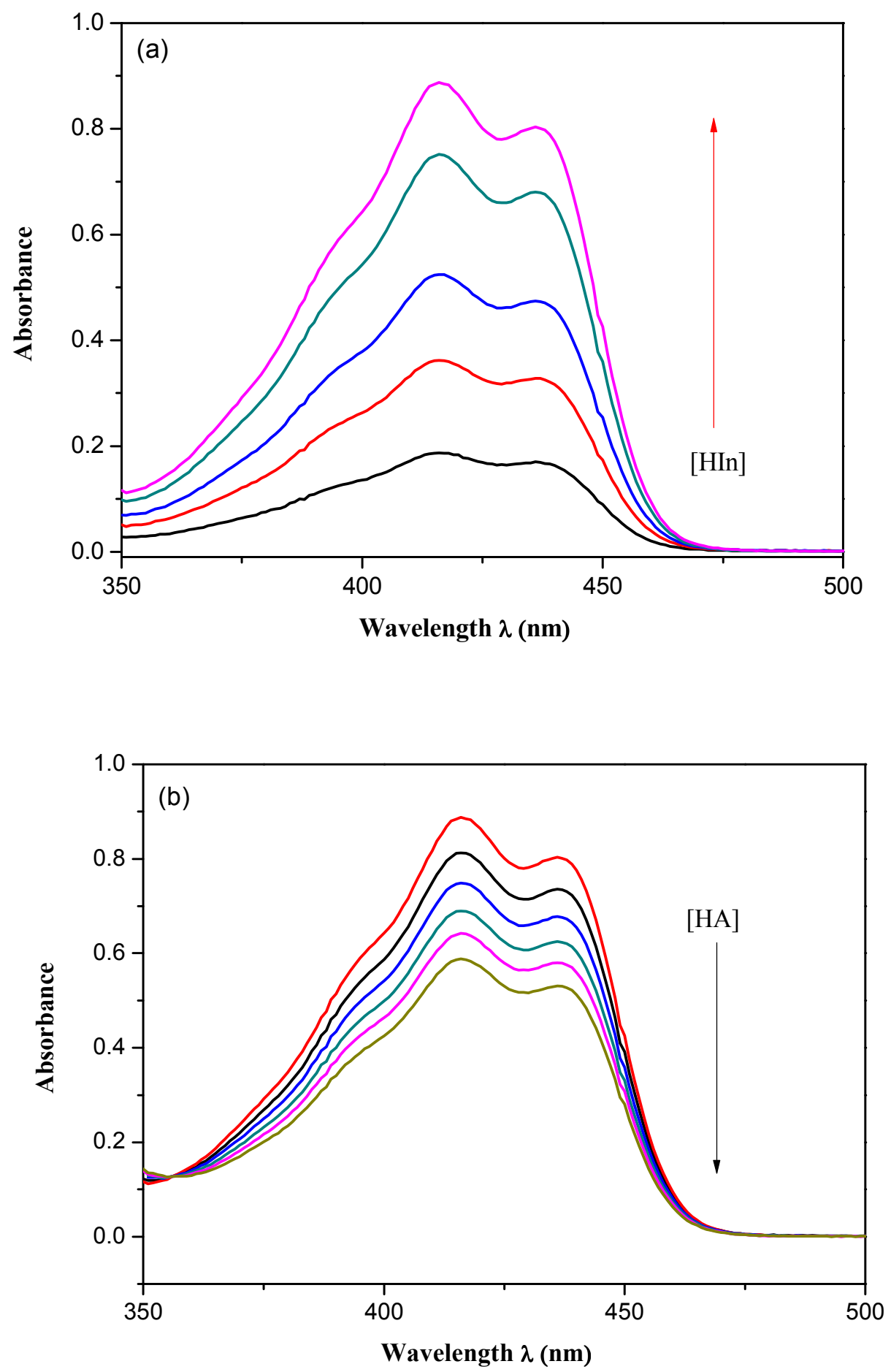

Figure S2 (a) The increasing absorbance during the deprotonation of the indicator $\mathbf{D}$ by the base. (b) The decreasing absorbance during the titration of the indicator anion by $\mathbf{4 a}$ in [BMPY] $\left[\mathrm{NTf}_{2}\right]$. 

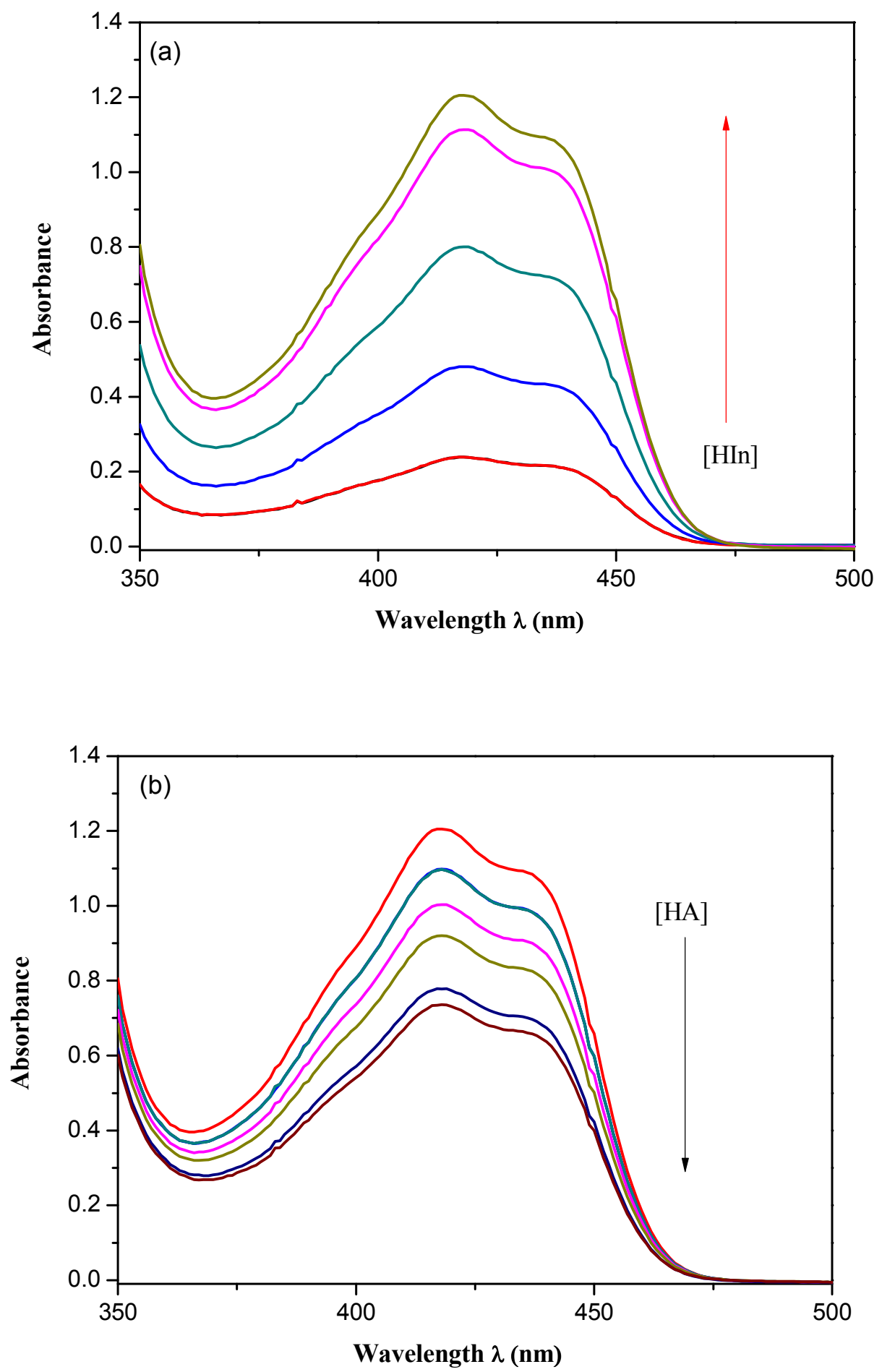

Figure $\mathbf{S 3}$ (a) The increasing absorbance during the deprotonation of the indicator $\mathbf{D}$ by the base. (b) The decreasing absorbance during the titration of the indicator anion by $\mathbf{4 a}$ in [Bmim][OTf]. 

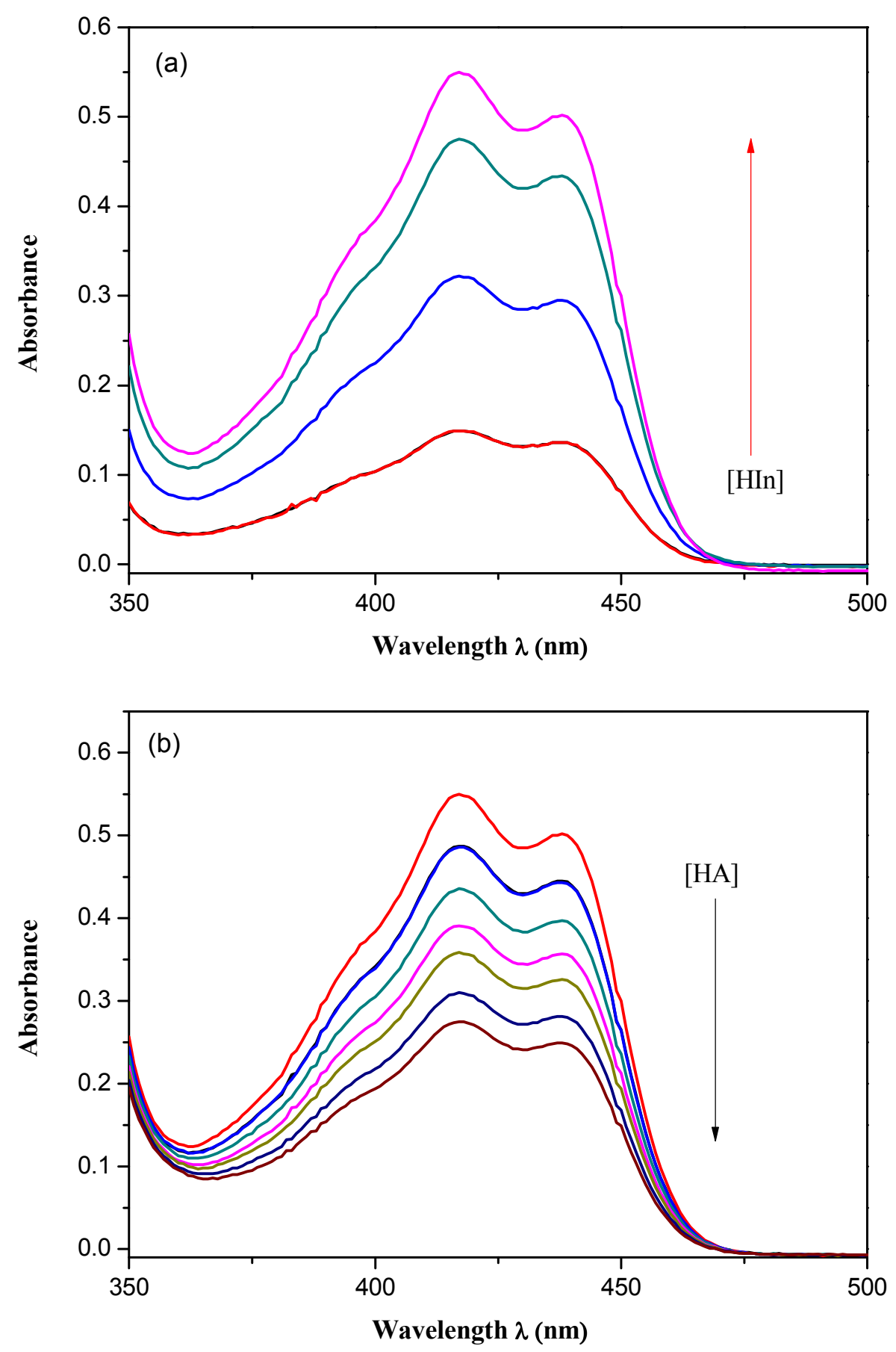

Figure S4 (a) The increasing absorbance during the deprotonation of the indicator $\mathbf{D}$ by the base. (b) The decreasing absorbance during the titration of the indicator anion by $4 \mathbf{a}$ in $\left[\mathrm{BM}_{2} \mathrm{IM}\right]\left[\mathrm{NTf}_{2}\right]$. 

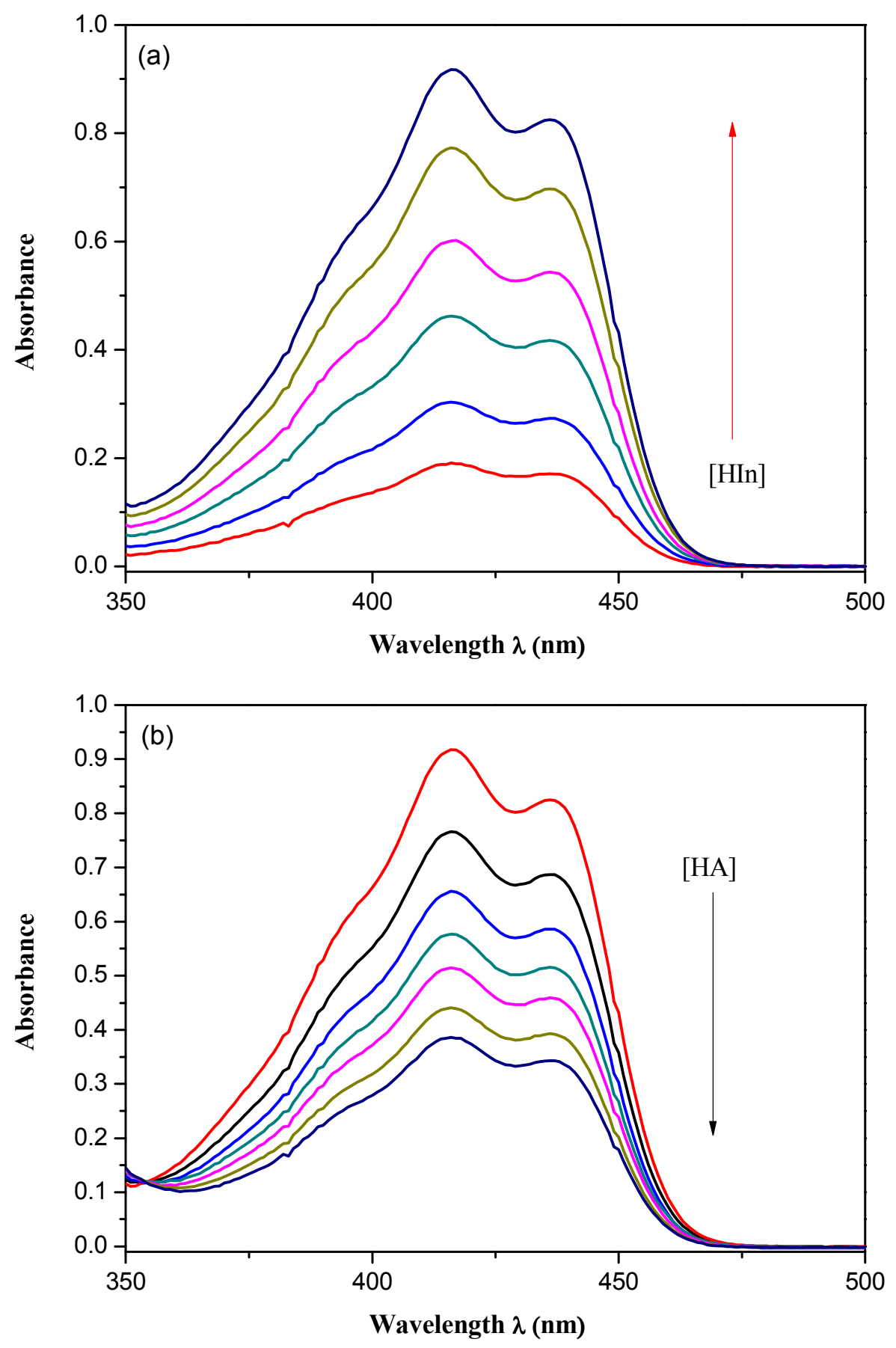

Figure S5 (a) The increasing absorbance during the deprotonation of the indicator $\mathbf{D}$ by the base. (b) The decreasing absorbance during the titration of the indicator anion by $\mathbf{4 b}$ in [BMPY] $\left.\mathrm{NTf}_{2}\right]$. 


\section{Synthesis and characterisation of amine triflates.}

The synthetic procedure: to a stirred solution of amine compound $(5 \mathrm{mmol})$ in $25 \mathrm{ml}$ methanol, equivalent molar of HOTf in $15 \mathrm{~mL}$ methanol was added dropwisely. The reaction mixture was refluxed for $5 \mathrm{hrs}$ and then cooled to ambient temperature. The solvent was removed in vacuo and the residue was purified by recrystallization (PE/DCM) and dried under vacuum. These salts are stored in a glove box due to their very hygroscopic property. The NMR spectra of triflate salts were recorded on a $400 \mathrm{MHz}$ spectrometer. HRMS spectra were recorded on an Orbitrap analyzer. 2,4,6-Collidine·HOTf (9): White solid; ${ }^{1} \mathrm{H}$ NMR (400 MHz, $\left.\mathrm{CDCl}_{3}\right) \delta 14.34$ (s, 1H), 7.34 (s, 2H), $2.78(\mathrm{~s}, 6 \mathrm{H}), 2.57$ (s, 3H) ppm; ${ }^{13} \mathrm{C}$ NMR $\delta 159.6,152.8,125.1,119.6$ (q, $\left.J_{\mathrm{C}-\mathrm{F}}=119.92 \mathrm{~Hz}\right), 22.1$, 19.3 ppm; HRMS $\left(\mathrm{ESI}^{+}\right)$: Calcd. for $\left[\mathrm{C}_{8} \mathrm{H}_{12} \mathrm{~N}\right]^{+} 122.0964$, found 122.0962. HRMS (ESI): Calcd. for $\left[\mathrm{CF}_{3} \mathrm{O}_{3} \mathrm{~S}\right]^{-} 148.9525$, found 148.9510 .

Triethylamine-HOTf (10): Colourless liquid; ${ }^{1} \mathrm{H}$ NMR $\left(400 \mathrm{MHz}, \mathrm{CDCl}_{3}\right) \delta 8.36(\mathrm{~s}, 1 \mathrm{H}), \delta 3.20$ (q, 6H), 1.37 (t, 9H) ppm; ${ }^{13} \mathrm{C}$ NMR $\delta 120.3$ (q, $J_{\mathrm{C}-\mathrm{F}}=118.0 \mathrm{~Hz}$ ), 47.0, 8.8 ppm; HRMS $\left(\mathrm{ESI}^{+}\right.$): Calcd. for $\left[\mathrm{C}_{6} \mathrm{H}_{16} \mathrm{~N}\right]^{+}$102.1277, found 102.1278. HRMS (ESI): Calcd. for $\left[\mathrm{CF}_{3} \mathrm{O}_{3} \mathrm{~S}^{-}\right]^{-} 148.9525$, found 148.9510 .

Piperidine-HOTf (11): White solid; ${ }^{1} \mathrm{H}$ NMR $\left(400 \mathrm{MHz}, \mathrm{CDCl}_{3}\right) \delta 7.52(\mathrm{~s}, 1 \mathrm{H}), \delta 3.19(\mathrm{t}, 4 \mathrm{H})$, $1.88-1.82(\mathrm{~m}, 4 \mathrm{H}), 1.70-1.65(\mathrm{~m}, 2 \mathrm{H}) \mathrm{ppm} ;{ }^{13} \mathrm{C}$ NMR $\delta 120.0$ (q, $\left.J_{\mathrm{C}-\mathrm{F}}=320.8 \mathrm{~Hz}\right), 45.4,22.4,22.1$ ppm. HRMS (ESI ${ }^{+}$): Calcd. for $\left[\mathrm{C}_{5} \mathrm{H}_{12} \mathrm{~N}\right]^{+}$86.0964, found 86.0969. HRMS (ESI): Calcd. for $\left[\mathrm{CF}_{3} \mathrm{O}_{3} \mathrm{~S}\right]^{-} 148.9525$, found 148.9510 .

\section{NMR spectra of amine triflate salts (9-11).}

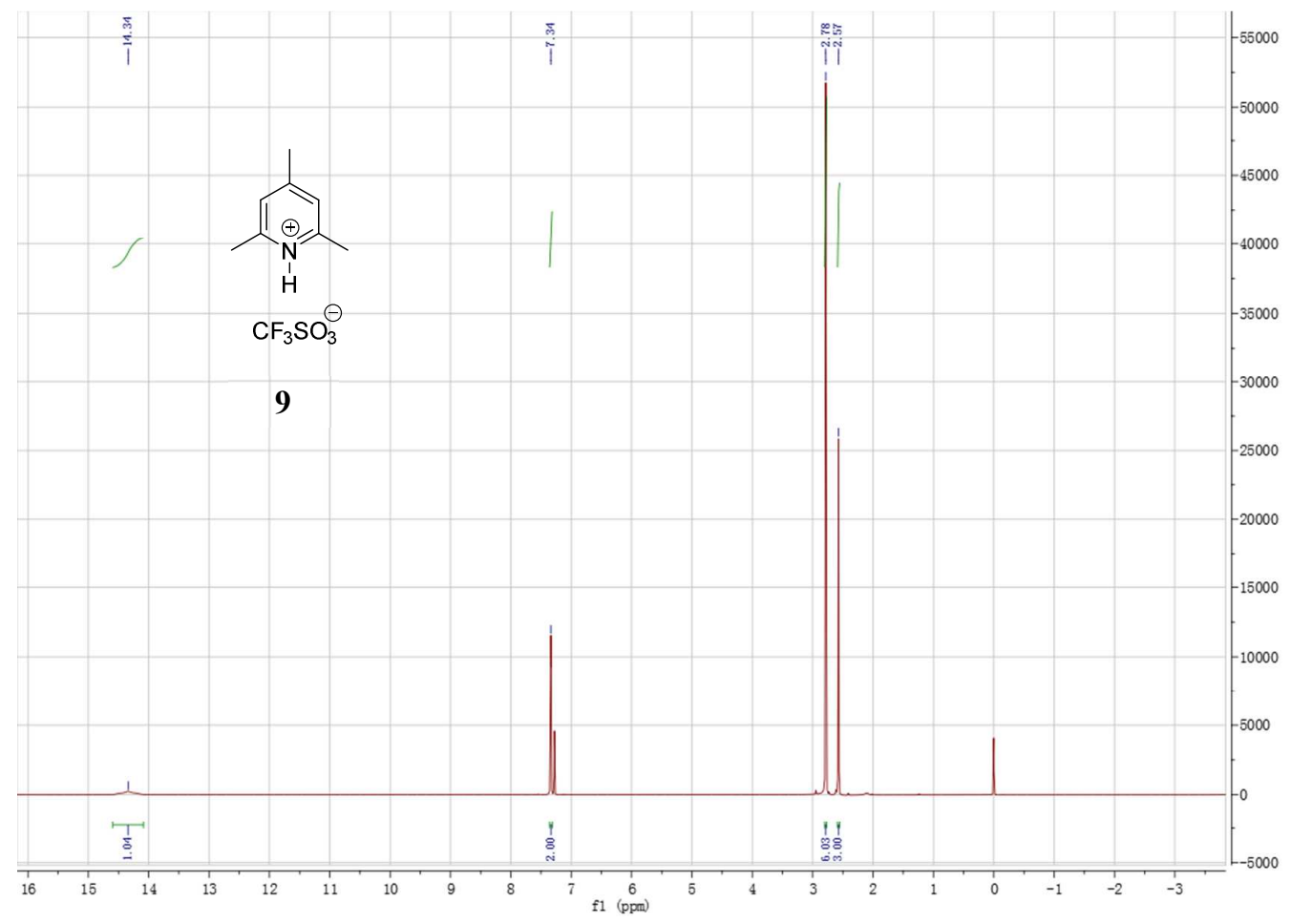



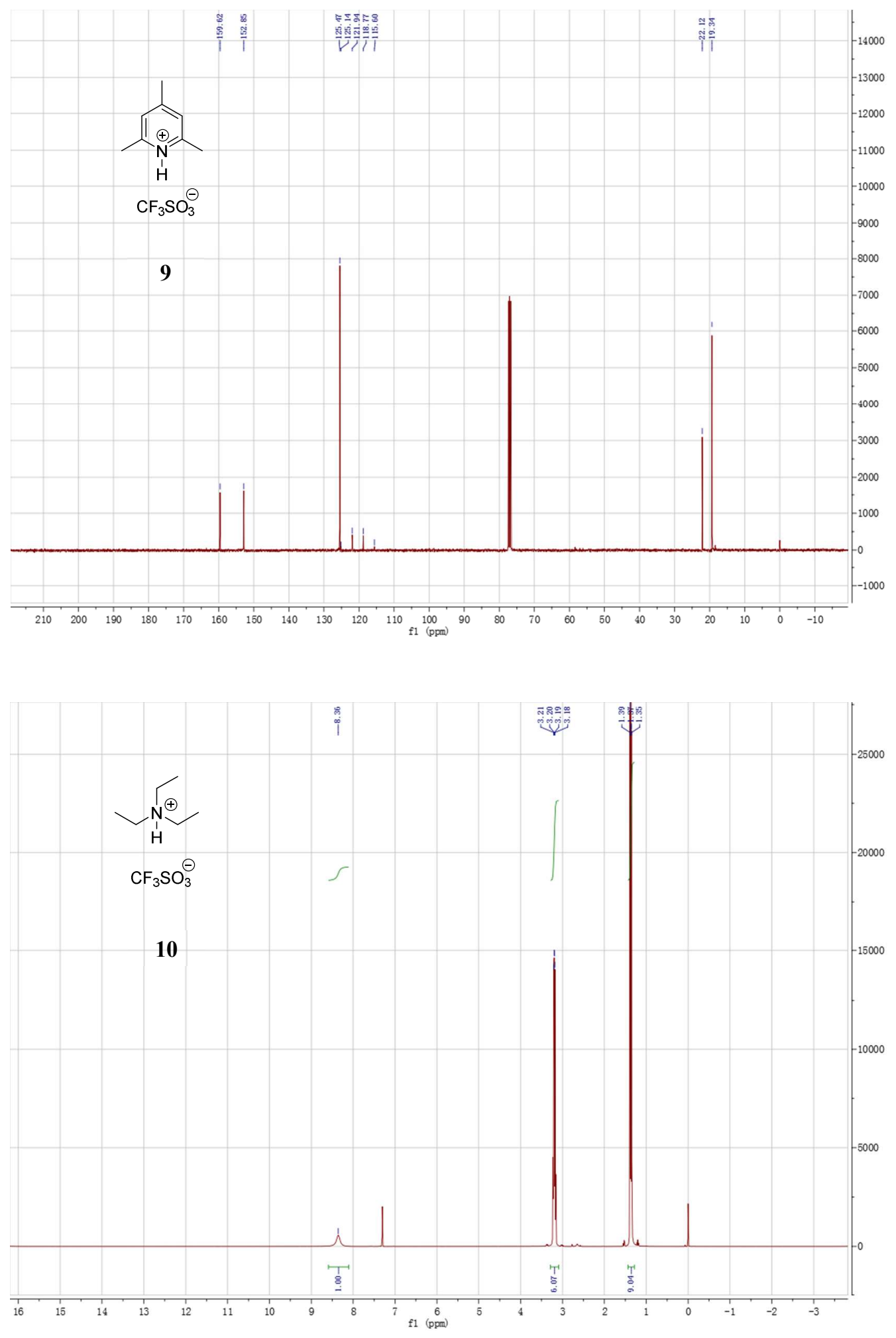

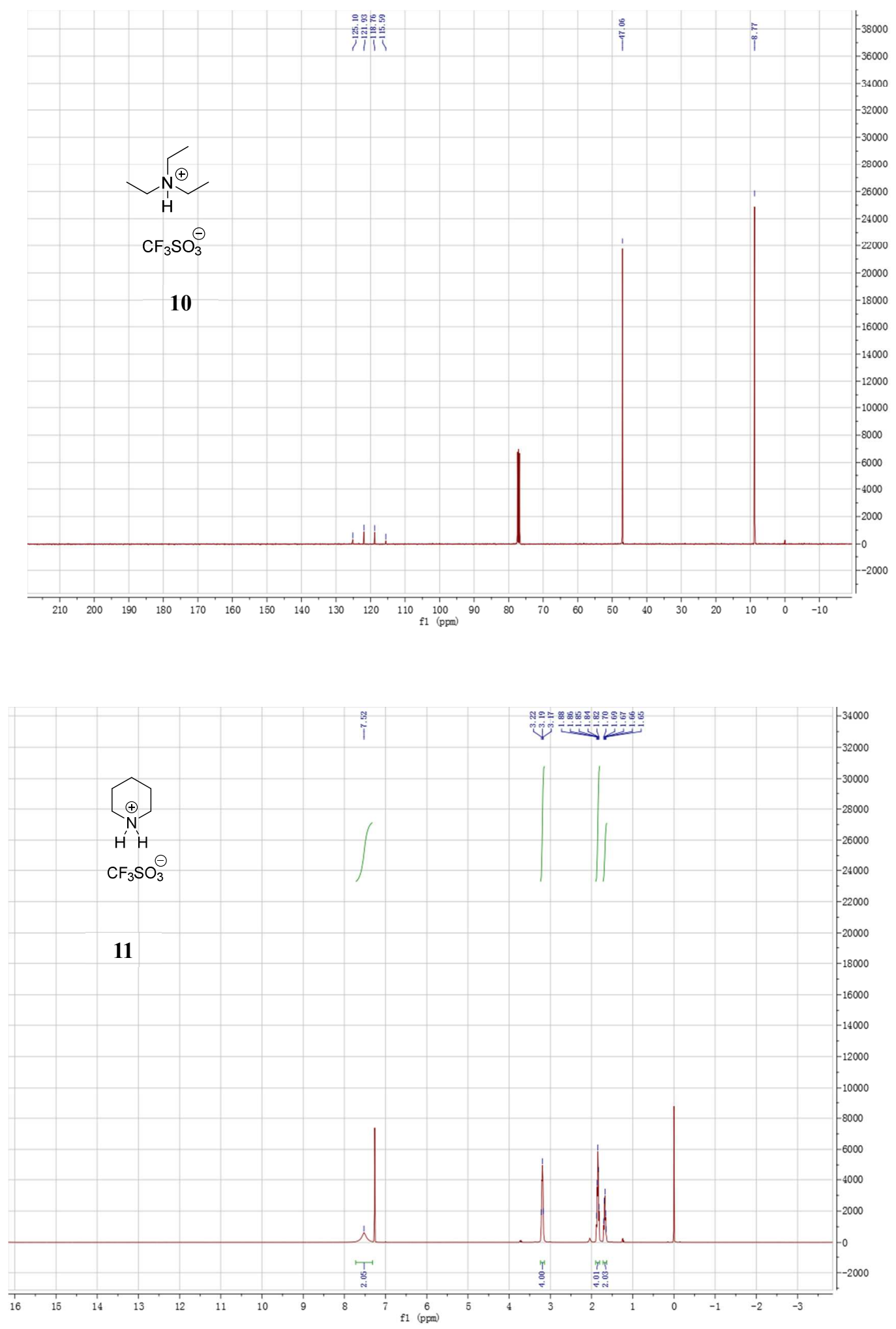


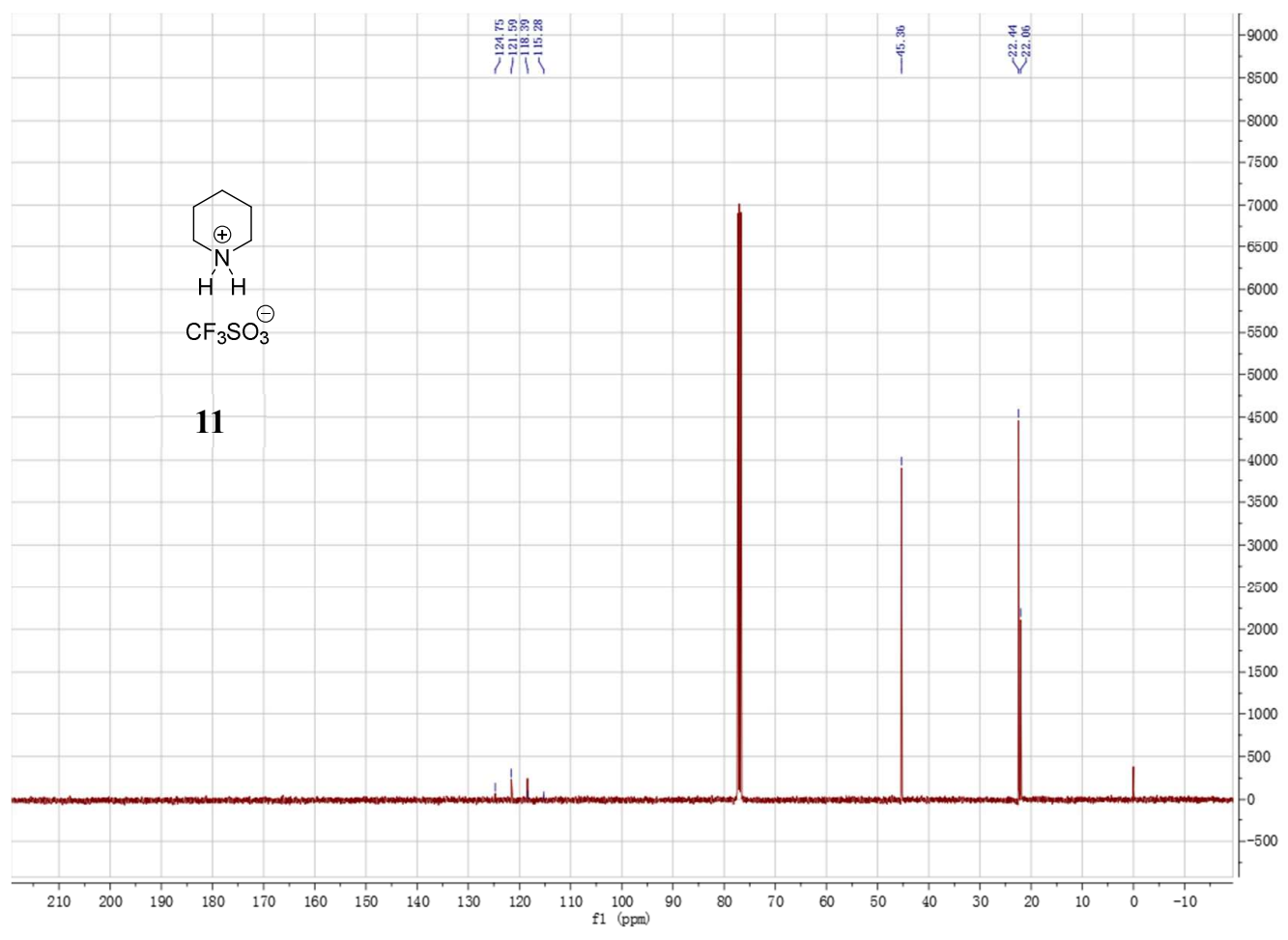

\section{Reference}

1. (a) Deng, H.; Li, X.; Chu, Y.; He, J.-Q.; Cheng, J.-P. J. Org. Chem. 2012, 77, 7291. (b) Wang, Z.; Deng, H.; Li, X.; Ji, P.; Cheng, J.-P. J. Org. Chem. 2013, 78, 12487. (c) Wang, Z.; Ji, P.; Li, X.; Cheng, J.-P. Org. Lett. 2014, 16, 5744.

2. Mao, C.; Wang, Z.; Ji, P.; Cheng, J.-P. J. Org. Chem. 2015, 80, 8384.

3. Samet, M.; Buhle, J.; Zhou, Y.; Kass, S. R. J. Am. Chem. Soc. 2015, 137, 4678. 